\title{
The Determinants of the Italian Support to International Criminal Courts
}

\author{
Claudia Pividori \\ University of Padova, Padova, Italy
}

\begin{abstract}
Since the beginning of the 1990s, Italian foreign policy actors have showed a steady and bipartisan commitment to international criminal justice institutions, the International Criminal Tribunal for the former Yugoslavia (ICTY) and the International Criminal Court (ICC) in particular. This paper aims at investigating the determinants of Italian foreign policy decisions to support and actively sponsor such institutions, as well as at providing a valuable account of the trajectory of the Italian foreign policy decisions with regards the issue under analysis. Starting with an historical account of the Italian contribution to the establishment of the ICTY and the ICC, the analysis will then focus on the internal and external determinants that may have contributed to the formulation of the Italian foreign policy. In this connection, the role played by political elites and their ideas about the Italian aspirated role as a responsible and ethical foreign policy actor will emerge as particularly relevant. Moreover, as observed in other cases connected to the Italian foreign policy in the broader area of human rights, Italy's commitment to international values raises the issue of the Country's incoherence as for the national implementation of those same values.
\end{abstract}

Keywords: Italy, International Criminal Tribunals, foreign-policy, role theory

\section{Introduction}

This case study aims at investigating the determinants of Italian foreign policy decisions to support and actively sponsor international criminal institutions, with a specific focus on the International Criminal Tribunal for the former Yugoslavia (ICTY) and the International Criminal Court (ICC).

The interest of the case here analyzed rests on several factors. First of all, the Italian foreign policy with regards international criminal justice institutions can be said to be characterized by the contemporary presence of two elements that otherwise rarely features the Italian foreign policy: continuity and success.

Despite of some minor fluctuations and a recent formalism, in the last 25 years the Italian foreign policy has steadily supported international criminal justice institutions. Such commitment, moreover, with its peak in the 1990s, is characterized not only by the fact of being bipartisan but also for being an expression of a unitary intent among different foreign policy actors such as the Government, the Parliament and, to a lesser extent, also the President of the Republic (Papisca, 1993).

The success of the Italian foreign policy in this connection stems not only from the fact that the Italian endeavor to attain the establishment of the ICTY and the ICC had objectively a positive outcome (obviously

Claudia Pividori, Research Fellow in International Law, Department of Political Science, Law and International Studies, University of Padova. 
there are other factors that have contributed), but also, and probably mainly, by the fact that the international community openly recognized the crucial and decisive role played by Italy.

In addition, the case under analysis is of particular interest because it presents some of the features that seem to characterize the Italian foreign policy in the broader area of human rights. Indeed, while on the one hand, the decision to support international criminal institutions is greatly influenced by ideas about Italy's role as exporter of universal values, on the other hand, such self-tailored role exposes the Country's incoherence with regards the translation of the international promoted values in internal commitments.

The first part of the paper describes the main forms of support that Italy had deployed to the establishment of international criminal tribunals. These range from the most classical forms of institutional/diplomatic efforts, to forms of second track diplomacy, or again, indirect forms of support such as the contribution of Italian experts/professionals. Particular events and key moments will be highlighted.

The second part of the paper focuses on the internal and external factors that have contributed to the formulation of the Italian foreign policy with regards the issue of international criminal justice institutions. Adopting a foreign policy analysis approach (Alden \& Aran, 2012) and relying on literature about role theory (Holsti, 1970; Harnisch, 2011), the aim of this part is to tentatively illustrate the rationale behind the Italian support to international courts. In order to do this, both international and domestic variables that may have played a role or influenced these foreign policy decisions will be investigated. The conditions that may have contributed to the positive outcome of the Italian foreign-policy will be also considered.

The third part of the paper presents some conclusions in order to provide a valuable account of the trajectory of the Italian foreign policy decision to support international criminal courts.

\section{An Historical Account of the Italian Contribution to the Establishment of International Criminal Tribunals}

\section{Concrete and Decisive Support}

Since the beginning of the 1990s until today, the Italian foreign policy has supported, despite a certain degree of fluctuation, international criminal justice institutions. Indeed, from the ad hoc Tribunals for the Former Yugoslavia and (to a lesser extent) Rwanda, to the International Criminal Court and mixed tribunals, especially the one for Lebanon, Italian foreign policy actors have showed a steady and bipartisan commitment to international criminal justice institutions.

As it will be synthetically presented below, such commitment was manifested in a number of different ways, ranging from the most classical forms of institutional/diplomatic efforts, to forms of second track diplomacy, or again, indirect forms of support such as the contribution of Italian experts/professionals.

The first manifestation of commitment in this regard can be detected amidst the war in Yugoslavia. On 22 January 1993, the then Italian Prime Minister, Giuliano Amato, announced the creation of a Commission of experts tasked to draft the Statute of an international criminal tribunal for the prosecution of individuals responsible of international crimes in the Balkans (Fabiani, 1993).

On 24 January 1993, with a decree of the then Ministry of Foreign Affairs, Emilio Colombo, the nine experts in charge to draft a Statute for the new tribunal had been appointed (Corrieredella Sera, 1993b). The Italian Government's intention was to submit the draft to the United Nations, to the Conference on Security and Cooperation in Europe (CSCE), or the London Conference. On February 17, 1993, Italy officially submitted the proposal to the CEE, to the United Nations Security Council and to the Government of the United States of 
America. Again, the Italian official position, this time expressed by Colombo, was that "the idea of the tribunal is not Italian. Italy only tried to realize it, with a view to a permanent tribunal" (Corrieredella Sera, 1993a; Rampoldi, 1993).

After the establishment of the International Criminal Tribunal for the Former Yugoslavia by the United Nations Security Council with Resolution 808 adopted on 22 February 1993, on 16 April 1993 the Italian Council of Ministers decided to present the Italian candidature to host the Tribunal in the attempt to curb any possible excuse not to make the Tribunal operative as soon as possible (Nava, 1993; Agorà, 1993).

The mobilization of the Italian Government continued even after the adoption of the Statute of the ICTY. Conso, who had then become Ministry of Justice, established a Working Group tasked to draft the domestic implementing legislation. On 14 February 1994, the Italian Parliament adopted the Law on cooperation with the ICTY. In the same year, the Italian Government seemed to have played a significant role in bilateral meetings at G7 for the appointment of ICTY Prosecutor, an issue that at the time was particularly divisive. Reportedly, indeed, Berlusconi played a decisive role in facilitating the dialogue with the then Russian President Eltsin thus favoring the election of the South African Richard Goldstone (Avagliano, 1994).

Besides direct forms of diplomatic support, the Italian commitment to international criminal justice institutions had been deployed also through more indirect forms. In this regards, the appointment of Italian experts and professional within the permanent structures or the conclusion of bilateral agreements in a number of judicial cooperation areas, while less manifest, greatly contributed to the effective functioning of said institutions and could be considered means through which States may exercise a certain degree of influence.

As a way of example, in 1993, at its 47th meeting, the United Nations General Assembly elected Prof. Antonio Cassese as member of the ICTY. The wide consensus received by the Italian candidate, the Ministry of Foreign Affairs press release commented, reflected the Italian prestige before the United Nations, the role played by Italy in promoting the establishment of the Tribunal, as well as the credibility of Prof. Cassese (Adnkronos, 1993). In particular, the press release underlined, the report submitted to the UNSC by the Italian Commission of experts represented a fundamental contribution to the deliberations of the Security Council.

In 1997 the Italian Government signed with the ICTY an agreement for the secondment of personnel and the very first agreement on enforcement of sentences. During the latter occasion, the then Minister of Justice, Flick, pointed out that "the strong Italian support for the objectives and activities of the Hague Tribunal is an integral part of the more general promotion by Italy of the establishment of international courts, as testified by the active role which Italy is playing in the work of the United Nations for the establishment of a Permanent International Criminal Court" (ICTY, 1997a; 1997b).

The idea of the permanent international tribunal had since the beginning of the Italian engagement with international criminal institutions linked with the activity to support the creation the ICTY. Indeed, the first steps toward what will later become the campaign for the launch of the Diplomatic Conference for the adoption of the Statute of the later ICC started when in November 1994 the Italian Government appointed Emma Bonino, a renowned supporter of international justice institutions, as Italian delegate before the UN General Assembly for the issue of death penalty, mandated to present the availability of Italy to host the Diplomatic Conference (Farkas, 1997).

While initially planned in 1995, the international conference for the establishment of the permanent tribunal was convened in 1998 (Cadalanu, 1998). The Italian availability to host the International Conference to draft the Rome Statute offered the international community a concrete temporal, logistic and negotiating 
perspective. The efforts deployed Italy during the summer of 1998 were remarkable. The considerable financial contribution was coupled with the finest diplomatic activity deployed to reconcile divergent and at time incompatible negotiating positions, but also with important inputs in terms of content and substance of the draft Statute.

\section{From Real to Formal Engagement}

Fourth Country to ratify the Rome Statute in 1999, after 1998 the Italian Government's commitment to international criminal justice institution remains constant yet it assumes different characteristics. Indeed, while in the last years the issue of international criminal justice institutions is recalled in high-level declarations, the Italian commitment is marked by a certain degree of formalism rather than real engagement.

More specifically, it has been observed that Italy had constantly referred to the issue of international criminal justice and its related institutions in the context of a number of high-level political pronouncements before international fora as well as in solemn declaration proclaimed by Ministers of Foreign Affairs.

In 2007, for the candidature to the Human Rights Council, the Italian Government stated that "Italy supports the International Criminal Tribunals and hosted in Rome in 1998 the United Nations conference that established the International Criminal Court". Moreover, in the same document, Italy committed to combat impunity, including by promoting the universalization of signatures and ratifications of the Statute of the International Criminal Court. In recent years, all Governments professed their faith into international criminal justice institutions, especially the International Criminal Court. In 2010, among the voluntary pledges and commitments presented in the framework of the Italian candidature to the United Nations Human Rights Council 2011-2014, at the fifth point Italy mentioned the fight against impunity, "also by promoting ratification of the International Criminal Court". Against this background since 2011 Italian Ministers Foreign Affairs have annually send solemn messages at the occasion of the International Day of International Justice, with the flag of the ICC flown in Rome at the Ministry of Foreign Affairs.

Against these backdrop, it can be observed that the formal adherence to the values of international criminal justice is no longer coupled with concrete supportive actions nor integrated into a broader strategic foreign policy framework. Significantly, in the 2007 "Report 2020. Choice of Foreign Policy" prepared under the aegis of the Ministry of Foreign Affairs, the issue of international criminal justice is completely absent. Not even once the words "International Criminal Court", "international criminal tribunals", "international criminal justice", "international crimes", "fight against impunity" are mentioned.

Moreover, the analysis of the recommendation formulated by Italy in the framework of the Universal Period Review, a Human Rights Council peer review mechanism focusing on the human rights situation in every UN Member States, shows that out of the 604 recommendation issued by Italy during the first two cycles, the issue of the Rome Statute was raised only seven times (addressing, respectively, Guatemala, El Salvador, DRC, Tonga, Vietnam, Brunei, Bhutan). If one consider that, on the contrary, the recommendation focusing on the issue of death penalty were 105, it appears quite clear that the diplomatic attention to the issue of international criminal justice not only is significantly declined, but it no longer matches the high-level declarations of support.

The fact that the solemn reaffirmation of values by Italian high-rank politicians is not longer coupled with active and concrete supportive actions does not however necessarily need to be interpreted in absolute negative terms. The fact that the international criminal justice institutions Italy had striven to set up are now well 
established and properly functioning (actually the ICTY is completing its mandate) has probably contributed to end the impetus of the Italian foreign policy in this particular domain. Having achieved the main objective, it may be understandable that proactive and supportive actions have been replaced by more formal of statement of support.

\section{Disrupted Continuity}

The only moment of fluctuation in the Italian trajectory of supportive foreign policy actions with regards international criminal justice institutions, and specifically the ICC, could be traced back in 2002 during the second Berlusconi Government.

Despite overwhelming Italian public support for the ICC and the fact that Silvio Berlusconi himself had publicly lauded the international tribunal, calling it a "historic turning point", leaked reports of the US ambassadors in Rome revealed that in 2002 Italy was ready to support the US President in his attempt to convince as many Countries as possible to sign an Article 98 agreement - which would have barred the handing over of US citizens to the ICC. In such reports, not only one of Berlusconi's advisors, Giovanni Castellaneta, told to the US ambassador that Italy would be willing to sign such an agreement, but in a separate meeting, the Italian Foreign Ministry official Giancarlo Aragon offered the US ambassadors suggestions as to how put pressure on the EU and gain support for the US position. Reporting back to Washington the US ambassador in Rome wrote that "once again, when president Bush asks Prime Minister Berlusconi for help, the help is forthcoming" (Maurizi, 2011).

This indulgence with the US attempt to undermine the ICC effectiveness and integrity was soon overcome by the prompt alignment with the EU position to substantially reject the US position. This was done on September 30, 2002, when the EU Foreign Ministers adopted a framework of EU Guiding Principles concerning arrangements between a State Party to the Rome Statute of the International Criminal Court and the United States regarding the conditions to surrender of persons to the court.

In conclusion, rather than a real negative stance or substantive disengagement of Italian foreign policy, this moment of fluctuation could considered as expressive of the "radical" Atlantism of Berlusconi's Governments (Brighi, 2013).

\section{The Dangers of Rhetoric Politics: Credibility and Coherence Become Relevant}

Despite the foreign policy success in the establishment of the ICTY and the ICC and the continuous reaffirmation of its faith in values such as international justice and the fight against impunity, Italy has not coherently translated its foreign policy actions at the domestic level.

The self-tailored role of champion or exporter of universal values more easily makes the issue of credibility and coherence to become relevant. With regard the issue here analyzed, coherence at the internal level not only concerns the area of judicial cooperation with international institutions, but also the area of prosecution and investigation of international crimes by domestic courts. Both areas are deeply dependent on adequate domestic legislation providing for the necessary legal basis for national courts to either comply with ICC cooperation requests or to activate domestic proceedings against individuals allegedly responsible for international crimes.

In this particular domain, the Italian commitment at the external level have not been coupled with a satisfying performance at the domestic level. Indeed, while the law on cooperation with the ICC was adopted in 2012, more than 10 years after the ratification of the Rome Statute, as of today Italy has not finalized the 
process of implementation concerning the substantive provisions of the Rome Statute.

\section{The Determinants of the Italian Support to International Criminal Courts}

The aim of this part is to tentatively illustrate the rationale behind the Italian support to international courts. At a first analysis, understanding the reasons for Italy to engage in such a foreign policy area is not straightforward. Apparently, indeed, Italy did not have a clearly identifiable strategic interest linked to the establishment of international criminal justice institutions. Moreover, differently from Countries such as Germany or Japan, Italy did not have any historical experience of international criminal prosecutions in its own territory. Nor had it a particular attitude or records in the exercise of criminal jurisdiction for international crimes committed abroad such as Spain or Belgium so to justify the commitment it had successfully demonstrated to such institutions.

In the following part, both international and domestic variables that may have played a role or influenced these foreign policy decisions will be presented with the aim to understand why Italy had decided to actively support international courts and to the extent possible why this foreign policy initiative had been eventually successful.

First of all, the general international context has represented an influential determinant for the articulation of Italian foreign policy decisions concerning the issue under analysis. Before the fall of the Berlin Wall the Italian foreign policy has been mainly determined by the iron logic of the Cold War. Indeed, the Italian foreign policy was entrenched and deeply dependent from the ideological confrontation between the East and the West. During several decades Italy was an object rather than a subject of foreign policy. The lack of direct responsibility in international affairs was guaranteed by external actors, naming the United States and NATO (Coralluzzo, 1992; Brighi, 2013).

After 1989, having lost its privileged role in the East-West confrontation, it is interesting to note that the domestic crisis which marked the years 1992-1994 did not translate in the paralysis of Italian foreign policy but into the opposite, naming a remarkable dynamism (Brighi, 2013). In the attempts to raise its international profile and its level of contribution, Italy had in fact engaged in a number of international activities, both at multilateral and regional level. In a very short time span, Italy lunched a number of initiatives such as the Pentagonale/Central European Initiative in May 1990, the Conference on Security and Cooperation in the Mediterranean in September 1990, and the proposal for a European seat at the United Nations Security Council in September 1990. It also got involved in the first Gulf War as well as in the first phases of the conflict in the Balkans, especially through the Brioni Accords, in October 1991 (Fossati, 2008).

\section{Elites and Ideas}

The domestic domain at the beginning of the 1990s was characterized by a deep political crisis that resulted in the end of the First Republic. For the period under consideration, the discontinuity provided by changes in domestic politics had enhanced the role of political elites (leadership) and, consequently, a probably growing weigh for their ideas about Italy's place and role in the world.

In connection to the area of international criminal justice institutions, the role of political elites seems twofold. On the one side, the engagement in this particular field seems to be attributable, at least in part, to the direct involvement and personal interests of a number of personalities. The role played by individuals such as Marco Pannella or Emma Bonino, or the personal interest expressed by Conso (Mastroluca, 2002) and the then 
President of the Republic, Oscar Luigi Scalfaro seems to represent fundamental drivers in the Italian decision to actively support the establishment of international criminal justice institutions.

As a support of this assertion, it can be mentioned the decision of the Government (at the time led by Giuliano Amato) on January 1993 to establish the Commission of experts. According to the newspaper "La Voce Repubblicana" this decision could be explained on accounts of a certain degree of pressure from the European Federalist Group and the Radical Party. Indeed, Pannella, leader of the Radical movement, had reportedly threatened to suspend the support to the Government concerning Italian foreign policy if clear actions against Serbia were not adopted (meeting 21 January 1993). While understating the influence of parliamentary dynamics, the decisive role played by Marco Pannella and the Radical Party (thus also Emma Bonino) in raising the issue of the creation of a tribunal for the former Yugoslavia has been confirmed by Amato during an interview with the author ${ }^{1}$. The then prime minister acknowledged that in 1993 he was very concerned with internal economic and financial issues and that it was thanks to Pannella that he got interested in the issue.

Always in terms of role of elites, the engagement in the area of international criminal justice institutions was also probably driven by the need of leaders to enhance Italy's role, prestige and credibility as moral actor at the international level. In this connection, the self-tailored role of exporter and champion of universal values seemed instrumental to, at least initially, counter the lack of hard power to deploy in the context of the Yugoslavian crisis and, secondly, by the desire of the Italian leadership to increase the Country international credibility in the midst of the internal crisis. Interestingly, from a number of interviews with Italian politicians and scholars, what emerged as constant is the idea that for Italy it was quite natural to engage in such area due to immaterial capital to invest (legal and philosophical tradition) and to rely upon. This is an element that could be observed in connection to other foreign policy issues such as the one on the death penalty, in the context of which the Cesare Beccaria's legacy is very often recalled as a sort of moral reference for the Italian engagement.

\section{Reaction to Marginalization and Wise Pragmatism}

At the international level, it could be observed that there are number of factors that not only opened a window of opportunity for Italy, but also contributed to the creation of favorable circumstances for the successful outcome.

First of all, as for the decision to support the establishment of the ICTY, the Italian aspirated role vis-à-vis the crisis in Yugoslavia was countered by the marginalization in which the international community relegated the Country (Caretta, 1993). While Italy wanted to play the role of mediator among the parties and, at the same time, maintain a channel of communication with Belgrade, its role had been deeply re-dimensioned. First of all, in 1991, Italy was excluded from the European troika dealing with the crisis in Yugoslavia. Secondly, once that in 1992 the United Nations had taken over the responsibility on the situation in the Balkans, Italy was excluded from peace-missions. Indeed, despite its reiterated willingness to participate in humanitarian interventions promoted by the United Nations such as UNPROFOR, in September 1992 Italy was excluded from peacekeeping operations on account of its status as a border Country. In addition to that, Slovenia and Croatia had explicitly objected to the presence of the Italian army in their territories due to revisionist claims raising in the Country. In early 1993 Italy was also excluded from the Contact Group.

\footnotetext{
${ }^{1}$ Interview n. 1 with Giuliano Amato, Italian Prime Minister in 1993, 20 December 2014, Rome. Interview n. 2 with Luigi Ferrari Bravo, Professor of International Law, 20 December 2014, Rome.
} 
In this context, the proposal to establish the ICTY could have represented a mean to counterbalance the lack of political involvement in the management of the Yugoslavia crisis. Indeed, the proposal to establish an international tribunal was just one of the many initiatives Italy was considering in order to gain some weight in the management of the crisis. Among others, the proposal to set up a registration mechanism for displaced people, the request to the United Nations to recognize the State of Macedonia, and the invitation in Italy of the Major of Sarajevo.

Worth mentioning in this regards is that the idea of international criminal tribunals was not originally conceived by Italian foreign policy makers. While it was already presented at the international level since the end of the World War II, there had always been a number of factors that contributed to a sort of stalemate. Very pragmatically and wisely, Italy was able to identify a window of opportunity, opened up by the crisis in Yugoslavia, and filled the gap by advancing concrete proposal and ideas. Indeed, while the idea to establish the Tribunal had been advanced before, Italy wanted to take the lead, being the one that prepared an executive project and submit it to those international institutions having the power to realize it. In those days, Amato said: "We want to be the one that put this idea into practice" (Corrieredella Sera, 1993a).

Then, obtaining the maximum output with the minimum effort, Italy was not only able to grasp the momentum for international justice institutions but also to consolidate it. As a matter of fact, once the ICTY had been established, any prospect to set up a permanent international court had raised significantly and the net efforts to be deployed were reduced. The fact that 1990-1999 was the United Nations decade of international law, that is a moment in time where the faith in international rule of law was particularly high, contributed to the breeding ground for the ICTY and then the ICC.

\section{Concluding Observations}

The previous parts of the paper aimed at providing a valuable account of the trajectory of the Italian foreign policy decisions to support the establishment of international criminal courts. What emerges from the attempt to identify the relevant international and domestic determinants that may have impacted on the articulation of Italian foreign policy decisions in connection with the issue under analysis is that a decisive role was played by political elites and their ideas about the Italian aspirated role at the international level. In other words, the role of a responsible and ethical foreign policy actor which could be legitimately claimed due to the legacy rooted in the ancient and deeply-rooted legal and philosophical tradition of the Country.

According to the analysis, the predominance of elites and ideas among the drivers that have contributed to the formulation of the Italian foreign policy with regards the issue of international criminal justice institutions is explained, on the one hand, by the presence of eminent and influential personalities personally committed to such an endeavor and, on the other, the profound crisis at domestic and international level.

The second driver that in combination with the role of elites and ideas may contribute to explain the Italian commitment to international criminal justice institutions is the marginalization from the management of the Yugoslavian conflict. In that circumstance, with no hard power to deploy, Italy could not but fall back on a different form of initiative. The subsequent engagement with the ICC, rather than a specific interest linked to a specific situation, could be interpreted as a wise and pragmatic attempt to capitalize the efforts already deployed and to consolidate the role of champion of the fight against impunity at international level.

The circumstance that the support to international criminal justice systems has not substantially varied on accounts of government changes, and thus changes in leaders, seems to confirm that the aspirated Italian role as 
moral actor, especially at the international level, is well rooted in political elites. The passage from a real to a more formal engagement is probably the consequence of the fact that the institutions whose establishment had been supported are now fully operational and therefore the need and the impetus for more supportive actions is ended.

Finally, as observed in other cases connected to the Italian foreign policy in the broader area of human rights (migrant's rights, freedom of religion), when Italy assumes the role of exporter of universal values at the international level, the issue of the Country's incoherence with regards the translation of the international promoted values in internally commitments become relevant.

\section{References}

Adnkronos. (1993, September 16). Ex Jugoslavia: Farnesina su nomina Cassese.

Agorà. (1993, April 17). Tribunale Internazionale: l'Italia offre la sede.

Alden, C.,\&Aran, A. (2012). Foreign policy analysis. New approaches. Abingdon: Routledge.

Avagliano, M. (1994, July 12). Occhio agli esteri. Intervista a Emma Bonino. Retrieved from http://www.emmabonino.it

Brighi, E. (2007). Europe, the USA and the "policy of the pendulum": The importance of foreign policy paradigm in the foreign policy of Italy. Journal of Southern Europe and the Balkans, 9(2), 99-115.

Brighi, E. (2013). Foreign policy, domestic politics and international relations. The case of Italy. London, New York: Routledge. Cadalanu, G. (1998, July 19). A Roma la firma del Tribunale ONU. La Repubblica.

Caretta, E. (1993, October 1). Andreatta chiede all'ONU più spazio per l'Italia. La Repubblica.

Coralluzzo, W. (1992). L'Italia e la crisi del Golfo: élite images e processi decisionali di politica estera. Teoria Politica.

Corriere della Sera (1993a, February 18). Crimini di guerra. L'Italiachiede un tribunale.

Corriere della Sera (1993b, January 25). Nominati i nove per il varo della nuova Norimberga.

Fabiani, L. (1993, January 23). Amato: "Norimberga per i serbi". La Repubblica.

Farkas, A. (1997, December 1). Tribunale penale permanente. Appello della Bonino all'ONU. Corrieredella Sera.

Fossati, F. (2008). Italian foreign policy after the Cold War. European Foreign Policy Unit Working Paper, 3, 118.

Harnisch, S. (2011). Role Theory. Operationalization of Key Concepts. In S. Harnisch, C. Frank and H. W. Maull (Eds.),Role theory in international relations. Approaches and analyses (pp. 7-15). New York and London: Routledge.

Holsti, K.J. (1970). National role conceptions in the study of foreign policy. International Studies Quarterly, 14(3), $233-309$.

International Criminal Tribunal for the Former Yugoslavia-ICTY (1997a, April 15). Tribunal signs Agreement with the Government of Italy for the secondment of personnel.

International Criminal Tribunal for the Former Yugoslavia-ICTY (1997b, February 1997). Italian Minister of Justice signs the very first agreement on the enforcement of sentences as yet another indication of Italian full support for international criminal justice.

Mastroluca, M. (2002, February16). Conso: “La giustizia è più debole senza una corte permanente”. L'Unità.

Maurizi, S. (2011, August 19). Wikileaks. Torture USA, B. a zerbino, L'Espresso.

Nava, M. (1993, June 17). Diritti umani. La nuova Norimberga. Corriere della Sera.

Papisca, A. (1993). Giustizia penale internazionale: il contributo dell'Italia alla costituzione del Tribunale internazionale sui crimini di guerra e contro l'umanità nella ex Jugoslavia. Pace, diritti dell'uomo, diritti dei popoli, VII-2. 117-131.

Rampoldi, G. (1993, March 26). Contro i criminali serbi 1' Occidente prepara il processo impossibile. La Repubblica. 